\title{
ENDOMETRIOSIS OF THE VULVA
}

Capt. G. M. P. Boyes, M.B., B.Chir., R.A.M.C., and Major A. M. WiLEY, M.Ch., F.R.C.S., R.A.M.C. Lately of B.M.H., Kluang, Malaya

The greater labium is an uncommon site for endometriosis. Cases have been described by Palmer (1925), Henry (1927) and others.

The lesion usually consists of a small red nodule painful during menstruation, slowly enlarging and consisting histologically of small blood filled cysts lined by columnar epithelium, in places forming typical endometrial glandular structures; the stroma consisting of fibrous tissue with some plasma cells and endothelial leucocytes containing haemosiderin. In some instances the histological picture has corresponded to that seen in the endometrium at the same phase of the menstrual cycle, as in Henry's case in which the tumour was removed two days before the onset of menstruation.

The following case is interesting for its short history and the great size of the tumour.

\section{Case Report}

History. An obese nulliparous Malay woman, aged 35 years, presented with a tender vulval lump, painful during menstruation and said to have been present, gradually enlarging, for five months. During the two weeks preceding her admission to hospital there occurred rapid and painful enlargement of the lump so that she had felt obliged to take to her bed. There was no history of injury or operation to the vulva.

On Examination. In the left greater labium there was a cystic lump the size of a full-term foetal head, with the clitoris stretched over its upper pole. The skin was tensed and shiny but not excoriated or inflamed and there were large veins coursing over its surface. The tumour appeared to be localized in the labium with no extension into the inguinal region or vagina (Figs. I \& 2).

At Operation. The cyst was readily shelled out under general anaesthetic but the wall was so thin it ruptured discharging dark brown fluid and some old blood clot. No attachment was noted to any other structure in the labium. Superfluous skin was removed and the cavity obliterated and drained.

Progress. The following evening she suddenly complained of a severe constricting pain in the chest and died, suffering clinically from a massive pulmonary embolus. Permission for post-mortem examination was refused, but this sudden death was possibly related to thrombosis of the leg veins occasioned by her enforced rest before admission.

Pathological Report. The tumour consisted of a single large cyst, measuring $8 \times 5 \times 2.5 \mathrm{~cm}$, having a fibrous tissue wall enclosing some old blood clot and with evidence of recent haemorrhage. Microscopically the lining consisted of endometrial columnar epithelium with areas of typical endometrial stroma in which were seen large phagocytic cells laden with haemosiderin (endo-

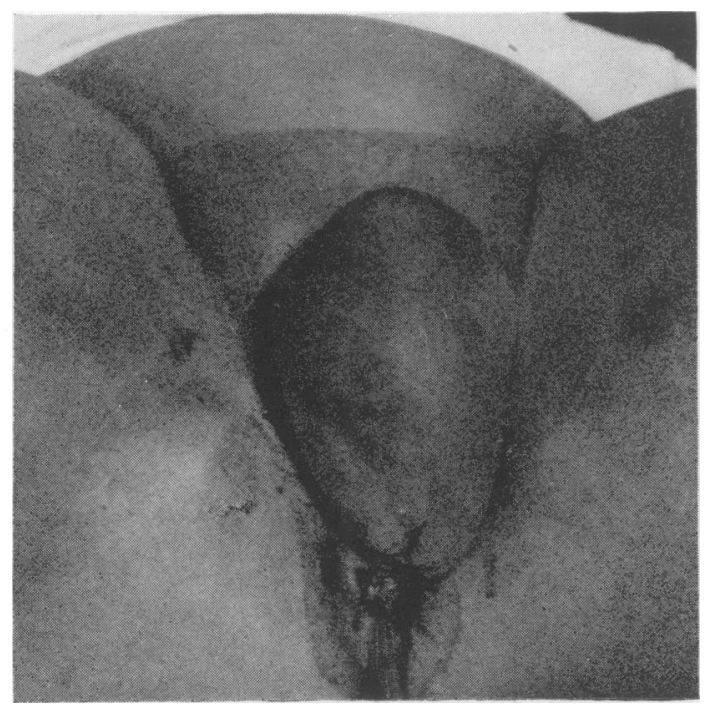

Fig. 1.-Photograph of endometrioma of the left labium. 


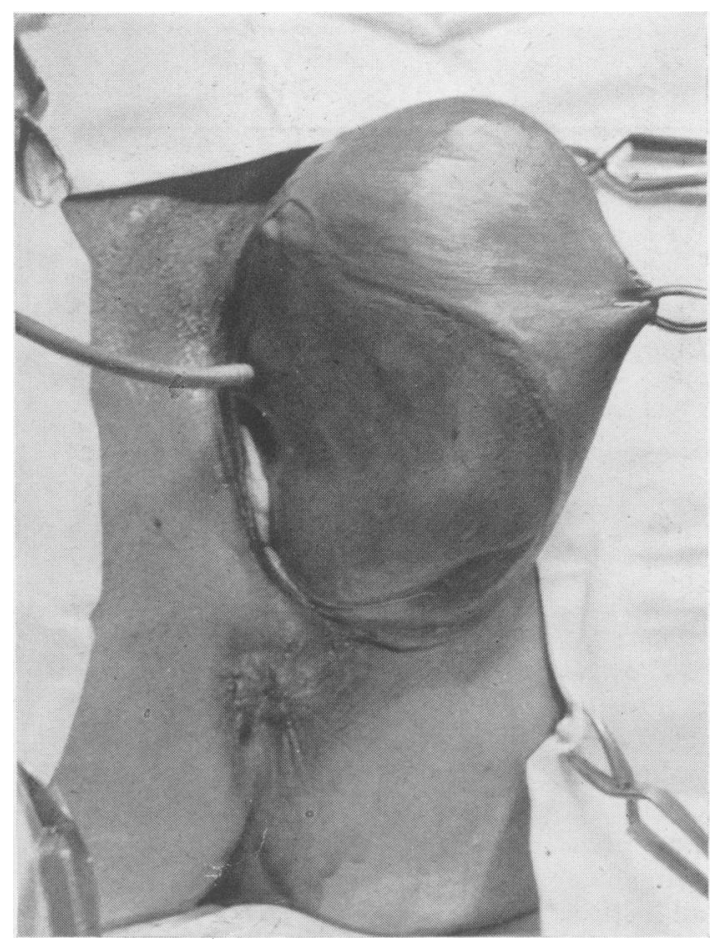

FIG. 2.-Photograph of endometrioma of left labium showing the greatly elongated clitoris stretched over the upper pole. A catheter is in the urethra and a swab in the vagina. thelial leucocytes), giving a histological picture of endometriosis.

\section{Discussion}

The origin of extra pelvic endometriosis has been the subject of much discussion. Samson's theory of auto-implantation into the peritoneum with migration cannot apply in this case as there was neither inguinal hernia nor any attachment between the cyst and round ligament. Other theories of spread along the lymphatic or venous plexuses and of direct implantation of decidua through a skin abrasion during menstruation can both explain the origin of this cyst.

\section{Summary}

A case of vulval endometrioma has been described, the tumour attaining large proportions in five months and causing severe symptoms. The origin of the tumour is briefly discussed.

We are grateful to Lieut-Colonel T. E. Field, R.A.M.C., for his pathological report.

\section{BIBLIOGRAPHY}

PALMER, A. C. (1925), Proc. Roy. Soc. Med., 18, 83-87. NEUWEILER, W. (1926), Schweiz. med. Wschr., 56, 545-548. HENRY, J. S. (1927), Surg. Gynec. Obstet., 44, 637-645.

KEHRER, E. (1929), 'Handbuch der Gynakologie,' Munchen 5(i,) 454-457, Veit \& Stoeckel.

\section{CARDIAC DISEASE}

(Postgraduate Medical Journal, February 1956)

Price 3s. 9d. post free

INTRODUCTION

Walter Somerville, M.D., M.R.C.P.

ANGIOGRAPHY

J. Norman Pattinson, M.B., B.Chir., D.M.R.D., F.F.R.

BEDSIDE DIAGNOSIS OF CONGENITAL HEART DISEASE

Walter Somerville, M.D., M.R.C.P.

SURGICAL TREATMENT OF CONGENITAL HEART DISEASE

W. P. Cleland, M.R.C.P., F.R.C.S.

PREGNANCY AND RHEUMATIC HEART DISEASE

Samuel Oram: M.D., F.R.C.P.
DRUG TREATMENT OF HYPERTENSION

E. G. McQueen, M.B., M.R.C.P., and F. H. Smirk, M.D., F.R.C.P.

\section{TREATMENT OF BACTERIAL} ENDOCARDITIS

Ian G. W. Hill, C.B.E., T.D., M.B., F.R.C.P.E., M.R.C.P., F.R.S.E.

THE MANAGEMENT OF COR PULMONALE J. F. Goodwin, M.D., M.R.C.P.

THE CARDIAC RISK IN ANAESTHESIA AND SURGERY

Graham W. Hayward, M.D., F.R.C.P.

Published by

THE FELLOWSHIP OF POSTGRADUATE MEDICINE

60, Portland Place, London, W.1 